\title{
Marrying in a single moment: Zimbabwean Baptist ethics and the management of kin relations
}

\author{
Leanne Williams Green
}

Not long after I began fieldwork in Zimbabwe's bustling capital city, I attended a wedding where the couple did not get married. The elaborate celebration - including a white wedding dress, a bridal procession, vows, gifts and a wedding cake - did not, I was told, make the couple husband and wife. This was a celebration of a marriage created many months before, at the payment of bridewealth. The officiating pastor was emphatic that the ceremony should not be interpreted as the last ' 5 per cent' of a ' 95 per cent' completed marriage. Those gathered were celebrating a relational transformation already fully achieved, and not one that could be extended across multiple events.

To see marriage as achieved decisively in a single moment runs counter to longstanding anthropological accounts of social life in sub-Saharan Africa. These literatures outlined marriage as a processual affair - as an unfolding of kin relations made through a series of social transactions over time (Radcliffe-Brown 1950; Bourdillon 2004 [1976]; Comaroff 1980a; Krige and Comaroff 1981; Kuper 1982). Radcliffe-Brown proclaimed authoritatively that 'to understand African marriage we must think of it not as an event or a condition but as a developing process' (1950: 49).

Yet across Southern Africa marriage by process has persisted in tension with recognizable moments of change within that process, from the first offers of marriage prestations to ritual recognition of firstborn children. While a series of events may be 'cumulative' (Murphree 1969: 29), such that the marriage process can be stalled or reversed at any point, they appear as discrete moments that punctuate the creation of new kin, with formative consequences (Krige 1981). For some decades, there has also been the growth of highly visible marriage events, often characterized by elaborate European-style 'white wedding' ceremonies, deserving of greater analytical attention (Pauli and van Dijk 2016).

These formal aspects of marriage have long crystallized concerns around social change. Scholars writing about the colonial-era towns of the Zambian Copperbelt debated whether urbanization undermined the stability of marriages, including the relevance of different lineage systems to the outcomes (Richards 1969 [1940]; Mitchell 1957; Powdermaker 1962; Parpart 1994). What they document, however, is not the mere erosion of 'traditional' marriage, but rather complex changes that took account of existing marriage procedures (Mitchell 1957: 29) while responding to competing ideals around gender rights, colonial control and emergent notions of domesticity (Parpart 1994; Ferguson 1999).

\footnotetext{
Leanne Williams Green is a socio-cultural anthropologist and a Junior Research Fellow at Trinity College, Cambridge. Her work focuses on ethics and morality, Protestant theology, and social change among middle-class Baptist Christians in Zimbabwe, where she has carried out fieldwork. Email: lw679@cam.ac.uk

(C) The Author(s), 2021. Published by Cambridge University Press. This is an Open Access article, distributed under the terms of the Creative Commons Attribution licence (https://creativecommons.org/ licenses/by/4.0/), which permits unrestricted re-use, distribution, and reproduction in any medium, provided the original work is properly cited.
} 
Alternative marriage types arose, adapted temporally to migration and to novel kinds of personhood.

The need to navigate these various forms of marriage has persisted, often experienced as an apparent touchpoint between 'modernity' and 'tradition' (Ault 1983). How is the notion of marriage as something that unfolds through an extended process reconciled with increasingly discrete moments of ritual performance in contemporary urban contexts? Below, I show how a group of Christians in Zimbabwe's capital, Harare, address discrepancies between marriage events and marriage processes by trying to realize relational change in a single moment of immediate transformation. Relations created processually generate ethical problems for Harare's Baptist Christians. Ambiguity in the status of relations produces confusion about responsibilities towards one another at any given point in time. Baptist ethics regarding autonomy and responsibility demand clarity on this front, which Harare's Baptist believers attempt to achieve by punctuating time with discrete events. The kinds of efforts I describe are those which allow people to be responsible to kin in ways most often achieved through processually generated relations, but to do so without allowing these kin to undermine their own moral autonomy. An attention to ethics offers insight into the meanings and evaluations conferred on marriage by this group, and thus on the wider symbolic and practical outworking of marriage events in time.

\section{Patterns of marriage and ethical engagements}

Before outlining the role that ethics plays in my argument, I address two patterns raised in recent work regarding marriage in Southern Africa. The increasing prominence of marriages that focus on singular events is frequently tied to the classed nature of 'white weddings' - so-called because of the wearing of an iconic white wedding dress. In Zimbabwe, as early as the 1930s, white weddings served as public signals of the rising status of black middle-class parents and their marrying children (West 2002); today, they remain signs of conspicuous consumption across the region (van Dijk 2017b; Pauli 2011).

Yet even where expensive white weddings appear emblematic of entrenched inequalities, they are not exclusively the preserve of the middle classes or elites, nor does a secure financial position necessarily motivate the hosting of elaborate marriage events. Costly wedding ceremonies can be an aspiration and achievement for 'non-elite' couples and their families, as in rural Namibia (Pauli and Dawids 2017). Referred to locally as 'struggle marriages', these couples have significant wedding events despite insecure financial positions. In other instances, those in a position to achieve middle-class marriages choose to remain single. They thus avoid the cost of wedding activities and also the financial demands placed on them by affines. Instead, they focus on meeting other resource-heavy demands, including the expensive private education of their children and the support of their natal kin (James 2017). Class distinction does not fully account for the prominence of white weddings on the one hand, nor for the avoidance of marriage on the other.

The latter example calls attention to another pattern noted by scholars: a precipitous decline in people contracting marriage at all (Hunter 2016; Pauli and van 
Dijk 2016; Solway 2016; White 2016; Pauli 2011). While seen as a recent phenomenon (Hunter 2016), work centring on both the colonial and postcolonial periods records the range of unions that have existed over time and have been more or less recognized as 'marriage' (for example, Powdermaker 1962), and, for Zimbabwe, the variety of conjugal relations that women in particular have negotiated, as detailed further below. A pattern that seems to signal decline in marriage may in fact extend a longer series of shifts regarding the types of relations into which people can and do enter, and the attendant kinship responsibilities or disavowals that these changes call into play. The two patterns taken together - for some, increasing aspiration for a white wedding amidst decreasing capacity to achieve marriage - lead Pauli and van Dijk to conclude that '[m]arriage in Southern Africa thus seems to be both normal and unattainable at the same time' (2016: 260).

For my Zimbabwean Baptist interlocutors, it is vital that marriage does indeed become attainable. Parishioners and church leaders attempt to modify practices and expectations in order to make marriage possible. During fifteen months of ethnographic fieldwork, I watched this group attempt to alter the temporalities in which relations were created between spouses and affines in order to make marriage more achievable ethically and financially. Where the transfer of bridewealth and a series of indefinite marriage events draws urban Baptists into an evolving web of kinship, their Baptist ethical ideology casts relations as produced in single, irreversible moments.

I suggest two reasons why 'ethics' is a valuable lens for approaching the question of how relations are conceived. ${ }^{1}$ First, for the Zimbabwean Baptists who conducted the wedding with no marriage, the stakes are moral ones. While familial expectations, class tastes and material constraints no doubt have a bearing on what is possible for the making of contemporary marriage, Zimbabwean Baptists navigate these factors according to explicitly stated ethical ideologies. By this I do not mean that sets of distinct moral rules are always identifiable or that the meeting of such rules is realizable, but rather that ethics are the terms in which my interlocutors articulate their choices surrounding the procedure of marriage. Where material constraints limit the choices available, this too is given a moral tenor.

Second, a renewed interest in the study of morality in anthropology brings new analytical strength to my discussion. Sometimes dubbed the 'ethical turn', what distinguishes these efforts from the discipline's more enduring attentions to morality is an endeavour to distinguish morality from the reiteration of social norms (Robbins 2007; Laidlaw 2014). Anthropologists have sought to problematize this relation between the moral and the social (Mattingly and Throop 2018) by examining those activities such as performing evaluations, reasoning about one's situation or making judgements that are foundationally ethical but need not be wedded to the reproduction of the social whole (Laidlaw 2014: 16-23). Consequently, new foci have come to the fore, including instances where persons face ethical dilemmas and potentially reject given moral rules (Zigon 2007), where societal values come into conflict, and where processes of cultural change are evaluated in ethical terms (Robbins 2004; 2007).

\footnotetext{
${ }^{1}$ For the sake of this argument, I do not distinguish between 'morality' and 'ethics'.
} 
Within these conversations, work highlighting processes of ethical self-cultivation and the 'ethico-temporal orientations' that can accompany these practices (Scherz 2013: 625) has been particularly influenced by Foucault (Robbins 2004; Mahmood 2005; Hirschkind 2006; Marshall 2009; Faubion 2011). My argument is informed by approaches that utilize his later works, where he explores the sense in which persons are not only subject to power but are also free (Foucault 1997). As James Laidlaw summarizes, human subjects 'have the capacity to reflect, to stand back from their own conduct and constitute it as an object of knowledge, and to act so as to change themselves' (Laidlaw 2017). The possibility that agents, both individual and collective, might employ this kind of 'reflective freedom' (Laidlaw 2014: 102) becomes the ground for an ethics.

Baptist religious practice, through a heritage of puritanism, ardently invites ethical reflection, in addition to explicitly defining itself in terms of religious freedom and autonomy. My interlocutors have a keen sense that there are accepted modes of behaviour in their cultural worlds. They have an equally strong notion of themselves as ethical actors, possessing the freedom to choose if they will fulfil obligations, and towards whom. They take this sense of moral freedom to be an intrinsic part of being human, as ordained by God, and presume that they are responsible for exercising and maintaining this freedom according to a Christian moral order. At times they make choices against their social and familial interests, or in opposition to their own material benefit. The claim to ethical freedom does not preclude practical concerns, but instead draws these concerns into a novel form of evaluation, culminating around issues such as the timing of marriage activities.

Before outlining the legal, social and ethical considerations entailed in marriage negotiations in Harare, a few comments about ethnographic setting and methodology are in order. The Christians described here are part of a Baptist network in

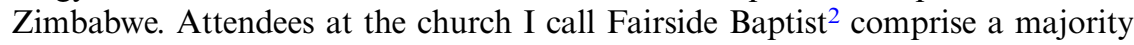
black middle-class congregation, with a significant portion identifying culturally as 'Shona'. ${ }^{3}$ This urban church has a cosmopolitan aesthetic. It attracts a few white Zimbabwean members and migrants from across the region, and so it refers to itself as 'multicultural', which it marks by its substantial use of English.

Between 2015 and 2017, during ethnographic fieldwork conducted in Harare, I lived with two different families who belonged to different Baptist churches. I spent many hours alongside members of this group and came to be included as a community participant. Although I share some common beliefs with many of my interlocutors, I am not a Baptist and did not become a church member of Fairside. ${ }^{4}$ As church leaders reported to me, around half of the regular attendees at the church do not become formal members and so my position was not particularly unique. The ethnographic data that I include below is drawn from participant observation in church activities and in the planning and execution of various

\footnotetext{
${ }^{2}$ All names used are pseudonyms.

${ }^{3} \mathrm{My}$ interlocutors use 'Shona' (anglicized from ChiShona) to represent the language that, alongside English, is most spoken among members of the congregation; they also use it to refer to the body of cultural practices by which they distinguish themselves from other, particularly white, Zimbabweans.

${ }^{4}$ The process of membership includes attending membership classes, baptism, an interview with elders, and a vote by the existing membership regarding formal admission to the church body.
} 
lifecycle events, and through semi-structured interviews and conversations with Fairsiders or Baptists affiliated with Fairside's larger network. ${ }^{5}$

\section{Marriage negotiations}

Not all who marry in Zimbabwe register their marriages, but those who do can choose to register them under either the Customary Marriages Act or the Civil Marriages Act. ${ }^{6}$ The former incorporates a bridewealth payment into the legal process. Like many in Southern Africa, most black Zimbabweans maintain the practice of lobola ${ }^{7}$ - the transfer of bridewealth between the groom and the family of the bride. When a couple decide that they would like to marry, they approach the bride's tete, a paternal aunt, who acts as a go-between for the couple and the bride's family (Chabata 2012). The groom enlists the assistance of his own intermediary - a munyai - usually a close associate or, for Baptists, sometimes a church leader. The meeting at which the lobola negotiations occur is conducted predominantly through the intermediaries. The bride's family draws up a list of items they are requesting, and a back-and-forth pattern of offers and counter-offers with the groom's munyai ensues. The amount requested is composed of money and gifts in kind, conventionally coming from the groom's lineage and historically split into two distinct pieces: rutsambo and roora. The former is described as giving the husband rights of sexual access, and the latter gives his lineage rights to the children from the union (Bourdillon 2004 [1976]: 41).

Those analyses that characterize marriage prestations in the above terms - primarily as a transfer of rights - have been challenged for their focus on bridewealth's 'jural' role (Comaroff 1980b; 1980c). John Comaroff asserts that, even given the recognition that African marriage may be a 'process', the notion of marriage as a transfer of rights still smuggles in the idea that there is a point at which a marriage status is conferred and the relationship is taken to exist 'indisputably' (1980c: 162). Based on Tswana ethnography, he argues that 'ambiguity' may be built into the cultural meaning of marriage. While bridewealth may dissipate some conjugal uncertainty, all unions remain 'potentially equivocal and negotiable' (ibid.: 163).

What are the implications for potential 'ambiguity' in marriage practice in Zimbabwe? Bourdillon tells us that 'there is no clear point at which a couple can say that they are now married whereas they were not married before' (2004 [1976]). This purported ambiguity has shaped, and has been shaped by, the history of legal and social interventions made regarding the temporalities of marriage. In successive iterations of a 'Native Marriage Ordinance' around the turn of the twentieth century, the colonial government struggled to codify marriage because it presumed an instantaneous 'moment' of marriage (Jeater 1993: 197).

\footnotetext{
${ }^{5}$ Conversations described occurred in a mixture of English and ChiShona. I report direct speech in the original language, unless otherwise noted.

${ }^{6}$ See Chapter 5:07 of the Customary Marriage Act (<https://www.law.co.zw/download/customary-marriages-act/>) and Chapter 5:11 of the Marriage Act (<https://www.law.co.zw/download/ marriage-act-chapter-511/>, both accessed 4 January 2019).

${ }^{7}$ I use 'lobola' throughout the article as it is the term most frequently used in popular parlance to describe bridewealth negotiation, although it is a loanword in ChiShona.
} 
Official registration required that bridewealth had to be paid in full, while demands from lineage elders that lobola be paid in cash moved the marriage prestation increasingly towards a 'single transaction' (ibid.: 221). This marked a significant divergence from the kind of lineage connections being generated in the 'long-term transfer of goods' (ibid.: 221). Legislative efforts and lobbying on the part of lineage heads served to codify a version of 'customary' marriage law that had not existed previously (Schmidt 1992: 106-8).

As legislators contended with defining marriage, new laws became tied to a particular and contested view of morality in the changing political economy of the colonial era. Diana Jeater, writing of Gwelo District between 1894 and 1930, shows the ways in which sexuality and marriage had been conceived locally as features of lineage, rather than a differentiated 'moral realm' (1993: 31). One's sexual relations were kinship concerns and not an issue of personal purity (ibid.: 30). The arriving European occupiers brought with them the attitudes of nineteenthcentury Britain, which not only treated marriage as an increasingly private affair but saw sexuality as requiring 'self-policing' (ibid.: 35-6). Policies restricting the terms of marriage became increasingly cast as 'morality legislation' (ibid.: 165). By the 1920s, these changes meant that sexuality could be understood in ways distinct from issues of lineage control. This characterization of sexuality as a matter of kinship responsibility or of personal piety cross-cuts the importance attributed to bridewealth and the status given to different conjugal relations.

Relationships in which no bridewealth was paid were and are widespread and escape many of the restrictions that often accompany the paying of lobola. For women moving to urban areas of Southern Rhodesia from the 1930s to the 1950s, 'proper' forms of marriage, whether recognized by the state, the church, or by in-laws, were necessary for accessing government-allocated accommodation, membership in women's clubs, and other forms of cultural and economic capital (Barnes 1999: 27, 33-4). The few women who could achieve this kind of marriage did not always desire it because other types of union offered them more flexible or profitable roles in the new political economy. These other types of union remain common today. Mapoto relationships, glossed by Barnes as 'temporary marriage' or 'informal marriage' (ibid.: 78), are relationships 'of the cooking pot' (see Jeater 1993: 178). In these cases, a woman lives in partnership with a man on her own terms, providing some domestic services for him but able to leave at will, taking her own property and sometimes some of his. A man with sufficient resources may also maintain a 'small house': that is, a second or third partnership outside marriage, distinct from his primary wife and family and potentially without their knowledge. Many conjugal relationships exist on a spectrum: couples may exchange gifts to signal their commitment with little expectation of family recognition, various forms of 'elopement' are frequent, bridewealth is not always paid, and there are varying degrees to which a marriage may persist 'in process' for an indefinite period (Meekers 1993).

My Baptist interlocutors reject relationships of this type that persist in degrees of ambiguity. They affirm ties where a clear and public commitment is made by a couple at one point in time, and they perform work on existing or potential relationships in order to make them fit this rubric. The regulation of relationships in time facilitates more exacting legal definitions, while a more 'precise' boundary for marriage allows churches to 'pass moral judgments on their members', determining whether 'their conjugal relations [are] either permissible or sinful' (Weinrich 
1982: 77). Baptists in Harare marry in ways that respond to this history of marriage ambiguity and a changing political economy, but most importantly to the moralizing of the marriage process. I turn next to the details of Baptist morality.

\section{Baptist moral autonomy}

Fairside Baptists prioritize ethical reflection as a practice in their religious lives. Weddings are occasions of particular ethical consideration (van Dijk 2017a) because they instantly transform relations, producing husbands, wives and affines, and thus new sets of moral responsibilities. Baptists at Fairside most often conduct lobola as an initial part of the wedding process and then are subsequently married under the Civil Marriages Act. This latter portion is sometimes a simple ceremony conducted with the pastor. However, the range of possible marriage events in which they might participate poses a problem for Christians in Harare. While a Zimbabwean couple can be expected or sanctioned to have sexual relations after some agreement is reached in the series of lobola negotiations, for Baptists a discrete moment of marriage is the boundary for appropriate sexual activity. The stakes for determining this boundary are high, and breaches can mean that the church takes decisive action to correct the member and bring them back to 'right living' within the group. At which ceremony is one married? Or, as one attendee at a church youth camp put it: 'So, when can I sleep with my wife?'

Fairside Baptists address the question of timing for sanctioned sexual relations and multiple wedding events through efforts like those I described above: a wedding for an already achieved marriage. These approaches are animated by the Baptist doctrine of moral autonomy, or a commitment to 'individual soul liberty and responsibility'. This phrase is one of the Baptist 'distinctives' taught in classes that prospective members attend before they can be considered for official inclusion in the Fairside community. At conversion, each believer gains an individual authority by the indwelling of the Holy Spirit, which entails a 'self-directing freedom and especially moral independence'. Individual autonomy is mirrored at the level of the congregation; Baptist churches are distinguished from other mission-derived churches by their democratic organization. Churches are affiliated through a union, but the congregation guides itself. Autonomy thus orders both personal religious lives and also the administration of the larger church body.

Guarding this moral autonomy is important for Baptist spiritual life. But there is a paradox embedded within the religious task: living a moral life includes fulfilling kinship responsibilities, which by their very nature have the capacity to infringe upon moral autonomy. Despite their puritanical heritage, Baptists in Harare do not reject worldly engagement (van Dijk 1992) and do participate in various lifecycle rituals. In the process, Baptist and non-Baptist family members alike make regular demands that pose challenges to the capacity of the individual to determine their own course of action. One way in which Baptist believers are advised to manage kinship relations is by controlling the temporality of pivotal moments of family relating.

How one relates to lifecycle practices is one means by which types of Christian adherence can be distinguished across the region. Within a broader religious 
'pluralism', one source of difference is whether a church is influenced by Pentecostal worship styles and ethics (Ranger 1995: 242). Pentecostalism in Zimbabwe often creates 'firm boundaries' for distinguishing between Christian lifestyles and 'traditional rituals and practices' (Maxwell 1995: 312), leading these groups to more virulently reject participation in the latter. Birgit Meyer's (1998) work in Ghana shows how a similar division between Pentecostal Christian practice and 'tradition' produces a temporal negotiation with modernity that treats 'tradition' as 'past'. Consequently, those seeking a Pentecostal future describe their efforts to 'make a complete break with the past': that is, to separate from the cultural practices that embed them in webs of familial influence (ibid:: 338). These links are 'demonized' and thus the risk to Christians lies in maintaining social ties that open them up to demonic influence or attack, a Christianized 'dark side of kinship' (Geschiere 2003).

By contrast, Fairsiders express their Christianity in a decidedly non-Pentecostal idiom. While they do regard conversion as a complete transformation that constitutes a rupture from one's previous moral self, they do not seek separation from 'culture' and family. The difference lies in the spiritual economy regarding sin. The moral risk posed to Baptist believers by participation in kinship rituals does not come from ancestral spirits (vadzimu) imagined as demons; the greater enemy is internal moral failing (see Robbins and Williams Green 2018). Fairside believers need to maintain a degree of moral autonomy because they are responsible for combating the internal sinfulness that might disrupt one's relations with God, which includes attributing authority to kin when it rightly belongs only to God. For instance, any indication that bridewealth transfer acknowledges or incorporates the agency of ancestors is symbolically removed from the process. Fairsiders must regulate the influence of kin even as they fulfil the commandment to 'honour your father and mother'. Consequently, Fairside's leaders reimagine marriage practices in ways that are culturally recognizable but whose form and meaning are determined by Baptist Christianity and not by marriage conceived as a process.

\section{The processual relations of lobola}

Marriage conceived as a process creates the Shona relational categories of muroora and mukuwasha, around which concerns about family obligations crystallize. Mukuwasha is the relation between the groom and his affines created through lobola, once he has given a 'token' of thanks to the parents of the woman he would like to marry. David Lan describes this relation between mukuwasha and the affinal lineage as the 'relationship that bears perhaps the greatest weight of ritual stress of any in Shona society' (1985: 85). Bridewealth is given in return for the life-producing capacities of the wife transferred from her lineage to that of the son-in-law, leaving his lineage always in some degree of debt (Lan 1985). Continuing indebtedness between wife-giving and wife-receiving lineages serves both parties (Bourdillon 2004 [1976]): fathers-in-law may request continued services from mukuwasha, and the groom may in turn be waiting to see if the wife is fulfilling her obligations (particularly her capacity to produce children) before he pays the final instalments of bridewealth.

Parents-in-law can indefinitely call upon their mukuwasha for favours, leading people to joke that you never really finish paying lobola. Several men complained 
to me of the demands that could be made on them by their affines, from large quantities of meat for funerals to costly foreign exchange transactions. Bourdillon cites a relevant proverb, also found repeated among contemporary university students (Chireshe and Chireshe 2010: 211): 'A son-in-law is like a fruit [or fig] tree: one never finishes eating from it' (Bourdillon 2004 [1976]: 43). I was engaged to be married throughout my fieldwork, and Fairsiders also cited this proverb to me (mukuwasha mukuyu haaperi kudyiwa), claiming my fiancé as their mukuwasha, and thus future labour and resources from him.

Rather than providing financial resources, a muroora performs labour for her affines. At a bridal shower for a Fairside woman, an elder's wife gave a speech instructing young women on the extreme lengths to which a muroora must go in order to serve her in-laws. They might challenge her by showing up unannounced, demanding food and treading dirt through her home (Vachitongokuisa pamuyedzo, they are putting you on trial/to the test). Among middle-class urbanites, where these kin may have contributed little to her husband's lobola, the woman is still obliged to act in ways that reflect Baptist gendered ideals of respect, despite the fact that they have little financial leverage over her.

Muroora and mukuwasha are iconic of the kind of moral obligations to kin entailed in the drawn-out process of paying lobola, and they index ties established between whole groups of people from different patrilines. These relations are valued but are also sources of significant conflict (Muchemwa and Muponde 2007; Bochow et al. 2017). Fairside Baptists emphasize the family values of care and honour for parents that mukuwasha and muroora embody. Yet they encounter the challenge of protecting other Baptist values in the face of demands brought by these same relations. One way in which they can attempt to do this is by remaking lobola negotiations in the image of a marriage conducted in a single moment.

On a long car journey during the cold August month of 2016, one husband explained to me how his Baptist Christian practice shaped the timing and terms of his marriage by lobola. Although he was not a wealthy professional, by the time Baba Eve married in his late thirties, he had been able to save a comparatively substantial amount of money. When visiting his in-laws at their rural home, he was praised because of the lobola he was able to offer. However, his express desire to complete the bridewealth transfer in a single transaction left his affines disconcerted. He explained to me: 'In our culture they say you don't finish lobola. Don't pay it all. Keep going ... I did it [all at] once.'

He gave two reasons for the decision to upend the practice of an extended process of lobola transfer. If he died, his parents-in-law might look to his brother to fulfil responsibilities as a mukuwasha, a burden Baba Eve should avoid placing on him. Additionally, Baba Eve did not think a Christian should remain in debt if they had the capacity to pay: 'You know the Bible says don't owe anybody anything except love. So that's why I challenge our culture. If I've got the means, if the Lord has given me the resources to pay off my lobola, why shouldn't I? Why must I owe this guy if I've got it?' As a father of two daughters, Baba Eve was determined that if his own future mukuwasha could pay all at once, then he would receive the amount in one transaction. As a tezvara (father-in-law, real or classificatory), this would mean foreclosing on the capacity to call on his mukuwasha for labour or resources as a condition of continuing debt. 
Baba Eve did not manage to pay his lobola in one transaction, but he did do so over the substantially shortened period of a single year, and he also modified the medium of transfer. He recounted that 'her parents were a bit uncomfortable' about his efforts to pay in a single transaction, but they could not refuse the payment he was offering. The year-long transfer was enough to mollify them, although this was also likely a result of the logistics necessary to acquire and deliver the cattle that the family had requested. His wife's family was poor, owning a single head of cattle. While the family had asked for seven cattle, 'half' as literal cows ${ }^{8}$ and the rest as the equivalent in cash, Baba Eve told his wife that he would not pay any of the lobola in cash. He knew that her father would 'take the money and spend it at the bottle shop' - that is, consume the wealth in liquor. As a Christian, he felt that his responsibility was to provide a long-term resource to the family. He determined to pay all of the lobola in cattle, so that they might use the animals to cultivate their land.

By his own estimation, Baba Eve's choices as a Christian contrasted with those of his wife's sisters' husbands. They were not 'believers' and so did not feel the same compulsion to meet their commitments to their in-laws. Although he thought it possible that the husbands were delinquent in payment because they simply did not have any money, Baba Eve knew that one of the men was 'gainfully employed' and had simply 'not bothered' to pay any lobola at all. A symbol of either laziness or greed, the failure was made more evident in the face of the poverty experienced by the wife's family, and entailed a rejection of the responsibilities demanded of a godly husband.

Lastly, Baba Eve explained that he would not request many of the additional charges often levied by a father-in-law. ${ }^{9}$ He considered gifts offered to the mother of the bride during lobola transactions 'normal and fair', due to her role in raising the daughter. But the items requested by the father often smuggled in what he termed 'funny things'. These included additional charges such as 'matekenya ndebvu', referring to when the bride pulled on the beard of her father as a child, a designated offence for which the prospective husband should pay.

Baba Eve called these additional payments a 'ploy'. His sekuru, his mother's brother, had explained the terms of lobola to him with the phrase 'uhu hudyire', glossed by Baba Eve as 'this is cheating'. A more standard translation of udyire is 'avarice', as when a father-in-law uses his daughter's potential suitors for material gain (Hannan 1974 [1959]: 697). Chimhundu's Duramazwi reChiShona (1996) outlines the meaning of udyire through the phrase "kufarira kudya zvevamwe mahara': to enjoy eating the goods of another for free. ${ }^{10}$ Bridewealth can be a way of gaining excessively at another's expense, of 'eating' greedily from the fruit tree of the mukuwasha. For Baba Eve, 'cheating' captures both greed and deception. A tezvara cannot ask for a substantial amount of money all at once

\footnotetext{
${ }^{8}$ Clearly, the requested seven cows could not be divided evenly in half, but this was Baba Eve's summary of the terms.

${ }^{9} \mathrm{~A}$ similar recommendation has been proposed by non-Baptist advocates of lobola reform, including Aeneas Chigwedere (1982).

${ }^{10}$ I thank one of the anonymous reviewers for drawing my attention to this definition. There is a more complex cultural and linguistic association between eating and sex made evident in this definition, but space limitations preclude further discussion of these connections.
} 
because it 'doesn't look good'. Instead, he will extract the sum by presenting a long list of smaller charges. Baba Eve considered this a ruse, intended to conceal greed. Although Baba Eve had paid these charges to his tezvara out of duty and respect, he would not request them of his mukuwasha as they exceeded what should constitute a 'token' of thanks.

Baba Eve's account signals attempts to meet familial responsibilities prudently in a temporally punctuated manner by contracting longer processes into briefer transactions, absent of persisting debt. Sansom describes 'squeezing debt out of bridewealth' into 'paid up' or 'instant bridewealth' as a strategy that transfers obligations towards affines onto other social and economic relationships (1981: 99). In Botswana, young marrying men told Jacqueline Solway that they did not want to 'owe anything to anybody' (2016: 312). The 'social debt' arising from extended rituals of bridewealth generation and payment that they eschewed was replaced with the heavily financial 'private debt' of white weddings and bridewealth paid immediately (ibid.: 309). Solway accounts for these changes as expressions of a new personhood embedded in a capitalist modernity, drawing on the notion of 'possessive individualism' (ibid.: 312). For Baba Eve, being free of debt has less to do with his capacity to display his individual wealth or class status than his ability to meet his responsibilities to his affines recast according to Baptist mores. Consequently, his commitment to moral autonomy does not plunge him headlong into individualism but compels him to navigate his relations with an exacting moral judiciousness.

Relative wealth and class difference between Baba Eve and his in-laws allowed him to negotiate the timing of lobola. For many young people marrying at Fairside, there is no such class disparity between the families of the bride and of the groom, and thus less leeway for a mukuwasha to control the terms of lobola. Church elders say that they are willing to intervene on behalf of the couple who want to marry, and to advocate for particular moral stances. In turn, they attempt to guide parents and family elders on the ways in which Christian parental values should also affect lobola.

\section{The elders advise}

In a booklet and series of sermons presented in late 2015, pastors and church elders at Fairside addressed confusion about how marriage can be constituted ethically in contemporary Zimbabwe. The booklet's opening question, 'When am I actually married?', ${ }^{11}$ underscores the premium placed on eradicating any potential ambiguity around marriage status. The problem in answering the question lies in what the writers describe as the clash of three worlds faced by Zimbabwean Christians - that of 'traditional Zimbabwean culture', that of secular law, and that of Zimbabwean Christianity. The European marriage ceremony is a 'cultural misfit' that 'creates social and moral dilemmas in African society', ${ }^{12}$ while the insistence on a 'church wedding' is unnecessary. According

\footnotetext{
${ }^{11}$ Taken from the 2015 Fairside Baptist Church Marriage Booklet, p. 3. (I preserve the church's anonymity by not giving the real title of the booklet.)

${ }^{12}$ Ibid.
} 
to the Bible, they say, marriage entails only three 'essential components': the end of the relation of 'dependency and filial obedience' towards parents (a 'leaving'), a 'definite beginning of a new relationship' between husband and wife (a 'cleaving'), and the 'allowance for the fullest, physical sexual expression of that relationship' ${ }^{13}$ All three components should be recognized in 'some public ceremony, acceptable to the local community'. ${ }^{14}$

These elements are fully sufficient, and the elders state emphatically that anything additional does not make the marriage more legitimate before God. Fairside thus aligns with other denominations in the Evangelical Fellowship of Zimbabwe, which, in their policies of recent decades at least, do not insist on church weddings (Weinrich 1982: 80). As the Fairside elders state:

a man and woman married in the cultural context of traditional, rural Zimbabwe who fulfil the above requirements of marriage, must be viewed as being married and must not be made to think that they also need to have a church ceremony to legitimize their marriage before God or the church. ${ }^{15}$

This stance represents a stark contrast to positions taken historically by many mission-derived churches (Ngundu 2010), which have pressured couples to have their marriages recognized through a church event. ${ }^{16}$ Instead, Fairside elders counsel such couples to ensure legal protections for their marriage. Registering a civil marriage prohibits polygamy and codifies inheritance. Legal protection then secures elements of Christian marriage that a church ceremony does not necessarily achieve, including the prioritization of the rights of the nuclear family over the rights of the lineage; registration codifies 'leaving' and 'cleaving'.

The 'ideal' procedure brings the legal, the 'traditional' and the 'Christian' conception of marriage together to be performed 'at the same point in time'. ${ }^{17}$ Practically, this means lobola negotiations with a pastor present to witness and to pray, with the signing of legal documents shortly thereafter, and thus all three worlds are compressed into a seamless package transacted across a single day. The booklet writers acknowledge how often this ideal is simply not possible, due to practicalities or family approval. If all three worlds cannot be made to coincide, then the young couple, in consultation with their families, need to decide which timed event will produce the marriage. The elders offer two possibilities, which they term 'lobola-as-marriage' and 'lobola-as-betrothal'. ${ }^{18}$

For 'lobola-as-marriage', the couple will treat the bridewealth transfer and the agreement between families as the creation of the marriage. The couple is advised

\footnotetext{
${ }^{13}$ Ibid., pp. 9-10, emphasis in the original.

${ }^{14}$ Ibid., p. 12. The approach described here is more historically and theologically developed by Onesimus Ngundu (2010; 2011).

${ }^{15}$ Ibid., pp. 12-13.

${ }^{16}$ A memorable instance occurs in Tsitsi Dangarembga's Nervous Conditions (1989), where the protagonist's parents are forced by her mission-employed uncle to participate in a white wedding, many years after their marriage union had begun. The depiction of the ritual is characterized by awkwardness and tragedy.

${ }^{17}$ Fairside Baptist Church Marriage Booklet, p. 14.

${ }^{18}$ Ibid. The elders use the terms 'lobolo-as-marriage' and 'lobolo-as-betrothal', pointing out that 'lobolo' is the noun of the verb 'lobola'. I modify their terms for the sake of consistency.
} 
to go to the magistrate and to receive civil recognition of the marriage as soon as possible afterwards. Again, they need not then have any kind of church ceremony, but if they desire one they must not treat it as 'a wedding ceremony initiating a marriage, but a Christian ceremony celebrating a marriage', ${ }^{19}$ as in the pastor's rendering of the event with which this article opened. The second option 'lobola-as-betrothal' - proves more challenging, because it means 'fly[ing] in the face of tradition by insisting that lobol[a] is nothing more than the seal of engagement and not marriage'. ${ }^{20}$ Extended family and community will expect the couple to be married once lobola is transacted. The couple will need to make a 'strong and very public statement and stand' that they are not yet married so that it is clear that their new gendered and sexual responsibilities towards one another have not yet begun. ${ }^{21}$

Marrying couples are pressed to make a choice between these two options. The importance of a distinct moment that moves a person from being single to married is closely connected to that which the marriage relation is supposed to represent. The relation of Christ to Christians is similarly one of immediacy: for Baptists, personal transformation involves a singular moment of instantiation - there is a moment of salvation. This relation between God, as Christ, and humans is brought about in a specific event, and the marriage relation between a man and a woman should index this relation in some capacity. The marriage moment thus parallels the salvation moment: as a single point in time through which and at which a new status (and new sets of relations) is established ethically. Additionally, the relationship between husband and wife entails a set of spiritually ordained responsibilities. Husbands must lead and also sacrifice themselves for their wives and children, while wives are to submit to their husbands. These gendered roles are initiated at marriage, and so the moment of marriage marks the boundary for sexual activity and for new obligations towards one another.

The counsel gathered in the booklet's pages consolidates the concerns shared by Baptist marrying adults and their parents. While they rarely referenced the booklet directly, I heard them regularly cite elders' spoken advice in their planning efforts. The booklet places value on lobola as a practice that 'historically has been so helpful in helping maintain stability of marriages and society'. ${ }^{22}$ However, the church elders suggest some reconsiderations because of the changing 'economic and social realities of our present day', ${ }^{23} \mathrm{a}$ tactful reference to deepening economic crisis and public complaints about the consequences of an increasing commodification of bridewealth (Chabata 2012; Chiweshe 2016). Bridewealth remains an appropriate gift offered to new affines. Couples increasingly pay the bulk of lobola themselves rather than relying heavily on resources from lineage members (see van Dijk 2017b; Spronk 2014), providing them with more control in kin interactions.

\footnotetext{
${ }^{19}$ Ibid., p. 15.

${ }^{20}$ Ibid., p. 16.

${ }^{21}$ Ibid.

${ }^{22}$ Ibid.

${ }^{23}$ Ibid.
} 


\section{'I will eat chicken and rice at your wedding'}

If a church ceremony is not considered necessary by elders, a white wedding is encouraged even less. Many congregants also reject the extravagance of such events. I heard leaders and young people decry the expense of the reception, decorations and clothing; these costs represent 'poor stewardship and potentially sinful extravagance' that promote 'individualism' and 'worldly display ... aimed to impress people rather than to genuinely honour God' ${ }^{24} \mathrm{~A}$ 'competitive' exhibitionism undermines what the focus of the event should be: public and communal celebration of God's vision of marriage. Here, sinful individualism is distinct from moral autonomy, as the latter entails some communal responsibilities and collective support. The proposed solution is to share the cost of the meal among community members, thus being 'far more in keeping with our traditional Zimbabwe culture as well as Biblical principles of stewardship and community life'. ${ }^{25}$

Yet the aspiration for a white wedding remains a point of considerable ambivalence across the congregation, as it does for many in Southern Africa. James (2017) notes how South African professionals with whom she spoke face a similar contradiction. They value 'frugality' and critique the 'competition' that characterizes the aspiring middle class, with whom they identify, which they say 'encourage[s] indebtedness' (ibid.: 8). But family relations and consumptive patterns place demands on one's pocket so that, as she puts it, 'the picture is one of considerable financial constraint alongside the longer-term moral ties which such payments are aimed at establishing' (ibid.: 4). In rural Namibia, too, couples find that, despite wanting smaller weddings, 'as soon as kin were involved, wedding plans grew in cost' (Pauli and Dawids 2017: 23). And too small a wedding might make one look as though one had no family at all (ibid.).

The pragmatic and moral judgements regarding family, white weddings and finances may be similar for many marrying in Southern Africa. The situation results, somewhat paradoxically, in an overall move towards increasingly eventfocused marriage for those few able to achieve it, and a persistent ambiguity around most other conjugal relations. I know of no cases where Baptists opted to share the cost of a celebratory meal among community members as the elders suggest. Still, what makes these Baptists stand out is their express need to dispel marital ambiguity without forgoing multiple desired wedding events and the resulting, if rarely achieved, strategy of condensing marriage activities into a single moment in time.

In the wedding I described at the outset, the couple chose 'lobola-as-marriage', and so a considerable span of time passed before their white wedding. This was likely a result of both the finances and the planning required to execute the elaborate event. There was a concerted effort to establish the point at which they had become married, so as to make clear that their married responsibilities and roles had begun before the white wedding celebration.

A couple who married the following year, Simba and Star, did pay lobola and host their white wedding on the same day, an impressive achievement praised by church members. The timing represented a clear divergence from the

\footnotetext{
${ }^{24}$ Ibid., p. 18.

${ }^{25} \mathrm{Ibid}$.
} 
couple's own plans. They had wanted to pay lobola and forego the white wedding entirely, thus avoiding the expense and the pressure of a large event. Simba reflected, watching a groomsman iron a wedding shirt into a crisp panel nearby, that he and Star had hoped to have a civil wedding at the courthouse and then an outdoor barbecue with their friends to celebrate. Instead, on this day, they found themselves rushing from Star's family home, where they had paid lobola in the morning, to the small mansion of a family friend, to dress for the white wedding ceremony hosted poolside in the back garden. The tight timing was the cause of enormous stress.

Earlier that morning Star had nervously waited several hours for the lobola negotiation to begin; the pressure of time and of money weighed heavily. She and Simba had saved for the bridewealth, but now the family was insisting on a white wedding. Much of the money earmarked for lobola had instead been used to pay for the European-style ceremony. Star knew how much Simba still had available, and she was worried that her aunts and uncles negotiating lobola would ask for much more than they had left.

When the (somewhat delayed) white wedding ceremony was finally concluded, guests loitered on the lawn. A church elder beside me spoke up, approving the same-day strategy. He explained that if a couple pays lobola and sleeps together but hosts their white wedding at a much later date, the bride may become pregnant and claim that the husband has 'raped' her because they have slept together without fully completing the marriage process. Conventionally, a significant portion of the bridewealth is transferred with the birth of the first child, usually around a year after first negotiations occur. The accusation of 'rape' suggests that a man is getting what he has not yet paid for. In the current economic situation, couples who have paid lobola regularly have to wait to host their white wedding simply because they need to save up more money. In the elder's example, the result is confusion about the timeline relating to when marriage rights and obligations are conferred.

A woman attendee, baby perched on her hip, also reasoned that hosting lobola and the white wedding simultaneously was a good strategy because it would cost less money overall. Holding the events simultaneously meant financing a single large meal for those gathered, instead of two. When I pressed both the elder and the woman attendee on the near impossibility of hosting all events on the same day, they both insisted that values of frugality and of sexual propriety were best achieved in a condensed timeframe.

When I asked others in the Baptist network why they thought that Star and Simba had been urged to have a white wedding at all, they suggested that the parents probably felt it necessary for maintaining family relations. From childhood, parents' and grandparents' siblings generate obligations in this regard, saying, 'I will eat chicken and rice at your wedding.' Similarly, marriage-age Baptists told me how their own parents expressed a desire to host their extended family for the large celebration. To hold all the events at once is the solution that comes closest to achieving a compromise between these competing demands.

Yet this strategy of coinciding marriage events remains nearly unachievable. Instead, a story I heard several times exhibits the family relations in marriage that Fairside Baptists most hope for. The story features a couple who have just completed lobola negotiations. The father of the bride accepts the lobola as a token of thanks, and then subsequently takes all of the cash from the negotiation, 
puts it in an envelope, and hands it back to the couple for their own use. The impact of this story sometimes brought people to tears, representing, as it did, the possibility of receiving and expressing family care in a Baptist idiom: a young couple fulfil their responsibilities towards their parents, while being supported financially to start their own nuclear family together. The return gift allows them to 'leave' and 'cleave'. A discrete moment of separation from parents at the creation of a marriage bond follows the pattern of punctuated moments of relational change. The story brings together the financial, familial and temporal elements of an ethical Baptist marriage.

\section{Conclusion}

Baptists in Harare seek to transform their social relations in a single moment. They aim to avoid the ethical ambiguities that arise from extending relational changes over a series of activities through time. When relations with affines or between spouses are undergoing processual change, Baptists face the challenge of stabilizing their ethical responsibilities. Marriage by single event resolves the ethical ambiguity but generates another conundrum. Zimbabwean Baptists continue to value family relations and seek to meet their responsibilities towards kin, which are ethical tasks more often realized through processual marriages. The efforts I have described here involve trying to meet these kin responsibilities in a punctuated temporality, so that they can control the degree of influence from families as well as reduce their debts and maintain the moral boundaries of marriage. This approach is seen as being more in keeping with a Baptist sensibility that accords people the right to make their own moral decisions about the degree and nature of these obligations.

By taking ethics as an object of analysis in its own right, we see how the stakes in marriage and family relations described here are more than concerns about social reproduction. Distinguishing analytically between the social and the moral also highlights the primacy of choice and accompanying restraints. Fairside Baptists are acutely aware of themselves as ethical actors who make decisions, and they make their own social action an object of ethical reflection. Their ethical concerns explain how and why their anxieties about marriage procedures come to centre on time. The temporality of the process is part of the very quality of relations being established (Stasch 2009), and all of these relations bear moral consequences. Baptists in Harare respond to the conflicting temporal qualities and moral obligations entailed in creating social relations by generating innovative ways by which they try to achieve a desired social life. Approaches in the anthropological study of ethics offer new insights into these processes of change.

\section{Acknowledgements}

This work was supported by the Wenner-Gren Foundation under Wenner-Gren Dissertation Research Grant 8876 and the F. G. Bailey Dissertation Research Fund at UC San Diego. Thank you to Matthew Engelke, Teo Zidaru-Barbulescu and other members of the 'Anthropology of Africa' seminar at the London School of Economics and Political Science, Rupert Stasch, Takunda Chabata, Julian Sommerschuh, Haleema Welji, Willard Mudzimiri, Max Bolt and two anonymous reviewers for Africa, and the members of 'Fairside Baptist' church. All errors are my own. 


\section{References}

Ault, J. (1983) "Making "modern" marriage "traditional": state power and the regulation of marriage in colonial Zambia', Theory and Society 12: 183-210.

Barnes, T. (1999) 'We Women Worked So Hard': gender, urbanization, and social reproduction in colonial Harare, Zimbabwe, 1930-1956. Portsmouth NH: Heinemann.

Bochow, A., T. Kirsch and R. van Dijk (2017) 'Introduction: new ethical fields and the implicitness/explicitness of ethics in Africa', Africa 87 (3): 447-61.

Bourdillon, M. (2004 [1976]) The Shona Peoples: an ethnography of the contemporary Shona, with special reference to their religion. Third revised edition. Gweru: Mambo Press.

Chabata, T. (2012) 'The commercialisation of lobola in contemporary Zimbabwe: a double-edged sword for women', BUWA! A Journal on African Women's Experiences 2 (1): 70-4.

Chigwedere, A. (1982) Lobola: the pros and cons. Harare: Books for Africa.

Chimhundu, H. (ed.) (1996) Duramazwi reChiShona. The ALLEX project. Harare: College Press <https://www.dokpro.uio.no/allex/gsd.html>, accessed 11 March 2021.

Chireshe, E. and R. Chireshe (2010) 'Lobola: the perceptions of Great Zimbabwe University students', Journal of Pan African Studies 3 (9): 211-21.

Chiweshe, M. K. (2016) 'Wives at the market place: commercialisation of lobola and commodification of women's bodies in Zimbabwe', Oriental Anthropologist 16 (2): 229-43.

Comaroff, J. (ed.) (1980a) The Meaning of Marriage Payments. London: Academic Press.

Comaroff, J. (1980b) 'Introduction' in J. Comaroff (ed.), The Meaning of Marriage Payments. London: Academic Press.

Comaroff, J. (1980c) 'Bridewealth and the control of ambiguity in a Tswana chiefdom' in J. Comaroff (ed.), The Meaning of Marriage Payments. London: Academic Press.

Dangarembga, T. (1989) Nervous Conditions: a novel. New York NY: Seal Press.

Faubion, J. (2011) An Anthropology of Ethics. Cambridge: Cambridge University Press.

Ferguson, J. (1999) Expectations of Modernity: myths and meanings of urban life on the Zambian Copperbelt. Berkeley CA: University of California Press.

Foucault, M. (1997) 'The ethics of the concern of the self as a practice of freedom' in P. Rabinow (ed.), Ethics: subjectivity and truth. The essential works of Michel Foucault, 1954-1984. Volume 1. New York NY: The New Press.

Geschiere, P. (2003) 'Witchcraft as the dark side of kinship: dilemmas of social security in new contexts', Etnofoor 16 (1): 43-61.

Hannan, M. (1974 [1959]) Standard Shona Dictionary. Second edition. Salisbury: Rhodesia Literature Bureau.

Hirschkind, C. (2006) The Ethical Soundscape: cassette sermons and Islamic counterpublics. New York NY: Columbia University Press.

Hunter, M. (2016) 'Is it enough to talk of marriage as a process? Legitimate cohabitation in Umlazi, South Africa', Anthropology Southern Africa 39 (4): 281-96. 
James, D. (2017) 'Not marrying in South Africa: consumption, aspiration and the new middle class', Anthropology Southern Africa 40 (1): 1-14.

Jeater, D. (1993) Marriage, Perversion and Power: the construction of moral discourse in Southern Rhodesia, 1894-1930. Oxford: Clarendon Press.

Krige, E. (1981) 'Summary and conclusions' in E. Krige and J. Comaroff (eds), Essays on Marriage in Southern Africa. Cape Town: Juta.

Krige, E. and J. Comaroff (eds) (1981) Essays on Marriage in Southern Africa. Cape Town: Juta.

Kuper, A. (1982) Wives for Cattle: bridewealth and marriage in Southern Africa. London: Routledge and Kegan Paul.

Laidlaw, J. (2014) The Subject of Virtue: an anthropology of ethics and freedom. Cambridge: Cambridge University Press.

Laidlaw, J. (2017) 'Ethics/morality' in F. Stein, S. Lazar, M. Candea, H. Diemberger, J. Robbins, A. Sanchez and R. Stasch (eds), The Cambridge Encyclopedia of Anthropology [online], <http:/doi.org/10.29164/17ethics>.

Lan, D. (1985) Guns and Rain: guerrillas and spirit mediums in Zimbabwe. Berkeley CA: University of California Press.

Mahmood, S. (2005) Politics of Piety: the Islamic revival and the feminist subject. Princeton NJ: Princeton University Press.

Marshall, R. (2009) Political Spiritualities: the Pentecostal revolution in Nigeria. Chicago IL: University of Chicago Press.

Mattingly, C. and J. Throop (2018) 'The anthropology of ethics and morality', Annual Review of Anthropology 47: 475-92.

Maxwell, D. (1995) 'Witches, prophets and avenging spirits: the second Christian movement in north-east Zimbabwe', Journal of Religion in Africa 25 (3): 309 39.

Meekers, D. (1993) 'The noble custom of roora: the marriage practices of the Shona of Zimbabwe', Ethnology 32 (1): 35-54.

Meyer, B. (1998) "“Make a complete break with the past": memory and postcolonial modernity in Ghanaian Pentecostalist discourse', Journal of Religion in Africa 28 (3): 316-49.

Mitchell, J. C. (1957) Aspects of African Marriage on the Copperbelt of Northern Rhodesia. Rhodes-Livingstone Papers 22. Manchester: Manchester University Press for the Rhodes-Livingstone Institute.

Muchemwa, K. Z. and R. Muponde (eds) (2007) Manning the Nation: father figures in Zimbabwean literature and society. Harare: Weaver Press.

Murphree, M. (1969) Christianity and the Shona. LSE Monographs on Social Anthropology 36. London: Athlone Press.

Ngundu, O. (2010) Mission Churches and African Customary Marriage: at what point should a couple married by African custom be recognised as married in the sight of God? Saarbrücken: Lambert Academic Publishing.

Ngundu, O. (2011) 'Mission churches and African customary marriage: a history of church marriages and a case for an African Christian customary marriage ceremony', Africa Journal of Evangelical Theology 30 (1): 35-53.

Parpart, J. (1994) "“Where is your mother?": gender, urban marriage, and colonial discourse on the Zambian Copperbelt, 1924-1945', International Journal of African Historical Studies 27 (2): 241-71.

Pauli, J. (2011) 'Celebrating distinctions: common and conspicuous weddings in rural Namibia’, Ethnology 50 (2): 153-67. 
Pauli, J. and F. Dawids (2017) 'The struggle for marriage: elite and non-elite weddings in rural Namibia', Anthropology Southern Africa 40 (1): 15-28.

Pauli, J. and R. van Dijk (2016) 'Marriage as an end or the end of marriage? Change and continuity in Southern African marriages', Anthropology Southern Africa 39 (4): 257-66.

Powdermaker, H. (1962) Copper Town. Changing Africa: the human situation on the Rhodesian Copperbelt. New York NY: Harper and Row.

Radcliffe-Brown, A. (1950) 'Introduction' in A. Radcliffe-Brown and D. Forde (eds), African Systems of Kinship and Marriage. London: Oxford University Press for the International African Institute.

Ranger, T. (1995) 'Religious pluralism in Zimbabwe: a report on the BritainZimbabwe Society research day, St Antony's College, Oxford, 23 April 1994', Journal of Religion in Africa 25: 226-51.

Richards, A. (1969 [1940]) Bemba Marriage and Present Economic Conditions. Rhodes-Livingstone Papers 4. Manchester: Manchester University Press for the Rhodes-Livingstone Institute.

Robbins, J. (2004) Becoming Sinners: Christianity and moral torment in a Papua New Guinea society. Berkeley CA: University of California Press.

Robbins, J. (2007) 'Between reproduction and freedom: morality, value, and radical cultural change', Ethnos 72 (3): 293-314.

Robbins, J. and L. Williams Green (2018) 'In what does failure succeed? Conceptions of sin and the role of human moral vulnerability in Pentecostal and Charismatic Christianity' in D. Kloos and D. Beekers (eds), Straying from the Straight Path: how senses of failure invigorate lived religion. New York NY: Berghahn Books.

Sansom, B. (1981) 'Cash down for brides' in E. Krige and J. Comaroff (eds), Essays on Marriage in Southern Africa. Cape Town: Juta.

Scherz, C. (2013) 'Let us make God our banker: ethics, temporality, and agency in a Ugandan charity home', American Ethnologist 40 (4): 624-36.

Schmidt, E. (1992) Peasants, Traders, and Wives: Shona women in the history of Zimbabwe, 1870-1939. Portsmouth NH: Heinemann.

Solway, J. (2016) "'Slow marriage," "fast bogadi": change and continuity in marriage in Botswana', Anthropology Southern Africa 39 (4): 309-22.

Spronk, R. (2014) 'Exploring the middle classes in Nairobi: from modes of production to modes of sophistication', African Studies Review 57 (1): 93-114.

Stasch, R. (2009) Society of Others: kinship and mourning in a West Papuan place. Berkeley CA: University of California Press.

van Dijk, R. (1992) 'Young puritan preachers in post-independence Malawi', Africa 62 (2): 159-81.

van Dijk, R. (2017a) 'Events ethics and their elasticity: weddings in Botswana and the exploration of the tacit extraordinary', Africa 87 (3): 462-78.

van Dijk, R. (2017b) 'The tent versus lobola: marriage, monetary intimacies and the new face of responsibility in Botswana', Anthropology Southern Africa 40 (1): $29-41$.

Weinrich, A. K. H. (1982) African Marriage in Zimbabwe and the Impact of Christianity. Gweru: Mambo Press.

West, M. (2002) The Rise of an African Middle Class: colonial Zimbabwe, 18981995. Bloomington IN: Indiana University Press. 
White, H. (2016) 'The materiality of marriage payments', Anthropology Southern Africa 39 (4): 297-308.

Zigon, J. (2007) 'Moral breakdown and the ethical demand: a theoretical framework for an anthropology of moralities', Anthropological Theory 7 (2): 131-50.

\begin{abstract}
Scholarship about Southern Africa registers a persistent tension between the prospect of relations created in a processual manner over time and the role of discrete ritual or lifecycle events. Marriage is one of the sites where this tension becomes particularly evident, not only in bridewealth transactions but also in an increasing prominence given to European-style 'white weddings'. For Baptist Christians living in urban Zimbabwe, the tension raises a host of ethical considerations. This group of Christians seeks to establish and maintain social relations that they value for cultural and for religious reasons, while also facing the ethical task of moderating the degree of obligation that these relations can exert over them. They do so in order to maintain the moral autonomy necessary to live ethical Baptist lives, and attempt to achieve this goal by creating marriages according to a model of immediate transformation, rather than one of gradual unfolding. I suggest that drawing from recent discussions in the anthropological study of ethics offers a way to discuss choice and evaluation in marriage practice in ways not reducible to class interest or social and material expediency alone.
\end{abstract}

\title{
Résumé
}

La recherche consacrée à l'Afrique australe est traversée par une tension persistante entre la perspective de relations créées d'une manière processuelle au fil du temps et le rôle d'événements de rituels discrets ou de cycle de vie. Le mariage est l'un des sites où cette tension se manifeste particulièrement, non seulement dans les transactions matrimoniales mais aussi en termes d'une proéminence croissante donnée aux " mariages en blanc » de style européen. Pour les chrétiens baptistes vivant dans les zones urbaines du Zimbabwe, cette tension soulève une multitude de considérations éthiques. Ces chrétiens cherchent à établir et à maintenir des relations sociales qu'ils apprécient pour des raisons culturelles et religieuses, tout en étant confrontés à la tâche éthique de modérer le degré d'obligation que ces relations peuvent exercer sur eux. Ils le font pour maintenir l'autonomie morale nécessaire pour mener une existence baptiste éthique, et tentent d'atteindre ce but en créant des mariages selon un modèle de transformation immédiate, plutôt qu'un modèle de déploiement progressif. L'auteur suggère que les discussions récentes menées dans l'étude anthropologique de l'éthique offrent un moyen du discuter du choix et de l'évaluation dans la pratique du mariage d'une manière qui ne se réduit pas seulement à l'intérêt de classe ou à l'opportunisme social et matériel. 